\title{
総合健診における血清フルクトサミンの評価 — $75 \mathrm{~g}$ GTT の成績とフルクトサミン值——
}

\begin{tabular}{|c|c|c|c|}
\hline 鈴木 啓吾 & 村尾 & 安達久美子 & 加瀬沢信彦 \\
\hline 野ミツエ & 木島 & 鈴木実干代 & 滝浪 利子 \\
\hline 中野 & 三浦はま㣽 & 森 政代 & 山本き \\
\hline
\end{tabular}

静岡健康管理センターにおいては 1985 年 1 月から空 腹時血糖 (FPG) と安定型へモグロビン A $1 \mathrm{c}$ (s-A 1 c) の組み合わせによって糖代謝異常のスクリーニングを行 っている。このスクリーニング方式を $75 \mathrm{~g}$ ブドウ糖負 荷試験 (75 g GTT) の成績と比較し, 糖代謝異常を早期 にみいだすという総合健診の立場からこの方式が妥当と 考えられることを前回の本学会大会で報告した。

近時血清フルクトサミン (FRA) の測定法が開発され たが，総合健診における糖代謝異常に関するフラクトサ ミン值の有用性についてはいまだ明らかでない。

われわれは FPG と s-A $1 \mathrm{c}$ の組み合わせ, FPG と FRAの組み合わせ, s-A $1 \mathrm{c}$ と FRA の組み合わせの各 々と $75 \mathrm{~g} \mathrm{GTT}$ の成績を比較検討した。

\section{対象と方法}

1988 年 4 月から 12 月までの間に当センターで総合健 診を受け，糖代謝異常を疑われて $75 \mathrm{~g}$ GTT を実施し たむのは 600 例であり, 全例に s-A $1 \mathrm{c}$ と FRA を測定 した。このうち総合健診時にも $\mathrm{s}-\mathrm{A} 1 \mathrm{c}$ と FRA を測定 したものは 195 例あった。FPG はブドウ糖酸化酵素電 極法, s-A $1 \mathrm{c}$ は東ソー HPLC による加瀬沢の安定型と 不安定型の同時定量法, FRA は BML 法で定量した。 $75 \mathrm{~g} \mathrm{GTT}$ の結果は日本糖尿病学会钓告値によって判定 した。

\section{成 績}

GTT 正常型は 110 例，境界型は 414 例，糖疗病型は 47 例, 糖尿病は 3 例, 腎性糖尿は 26 例であった。

各型の FRA の平均值士SD は, 正常型 $2.554 \pm 0.218$ 境界型 2.643土0.229, 糖尿病型 $2.896 \pm 0.266$, 腎性糖 尿 2.596士0.231，糖尿病 $3.867 \pm 0.551$ であった。全 600 例の平均值 $\mathrm{SD}$ は 2.651士0.260 であった。

FPG, s-A 1 c と FRAの 3 つのうち 2 つの組み合わせ

\section{Evaluation of Serum Fructosamine in MHTS.} 2. Results of $75 \mathrm{~g}$ OGTT and Serum Fructosamine.

財団法人静岡健康管理センター
についてみると, FPG と s-A $1 \mathrm{c}$ の相関係数は 0.502 , FPG と FRA の相関係数は 0.417, FRA と s-A $1 \mathrm{c}$ の 相関係数は 0.388 であった。

総合健聄時と $75 \mathrm{~g}$ GTT 実施時にとあに s-A $1 \mathrm{c}$ と FRA を測定した 195 例について，健診時とGTT 時の FPG，FRA および s-A $1 \mathrm{c}$ の值を比較した。健診日か ら GTT 実施日までの期間は， 2 週間まで 29 名，3 週 間 59 名, 4 週間 38 例, $5 \sim 8$ 週間 49 例, 9 12 週間 14 例, 13 週以上 6 例であった。 9 週以上の 20 例を除いた 175 例の平均間隔は 24.8 日である。FPG は 108.0 0 ○. 9 $\mathrm{mg} / \mathrm{dl}$ から $104.0 \pm 9.4 \mathrm{mg} / \mathrm{dl}$ 亿減少(減少率 3.7\%)， FRA は $2.67 \pm 0.24 \mathrm{mmol} / l$ から $2.60 \pm 0.23 \mathrm{mmol} / l$ に減少（減少率 $2.6 \%$ ), s-A 1 c は $5.36 \pm 0.32 \%$ 加ら $5.31 \pm 0.33 \%$ に減少（減少率 0.9\%）した。s-A $1 \mathrm{c}$ の 変動が最小であった。

75 g GTT 結果が腎性糖尿と境界型であったあのを除 いて, 正常型群 41 名, 糖尿病型群 20 名のみについて, 健診恃の FPG と s-A $1 \mathrm{c}$ の組み合わせ, FPG と FRA の組み合わせ, FRA と s-A 1 c の組み合わせのそれぞ れの場合に, 正常型群と糖尿病型群の相関楕円を作製し た。3つの組み合わせのうち正常型群と糖疗病型群の分 離が最も良好なものは FRA と $\mathrm{s}-\mathrm{A}_{1 \mathrm{c}}$ の組み合わせで あった。

GTT 正常型 110 名中 FRA が 2.8 未満のもの 97 例, 糖尿病型 47 例中 FRA が 2.8 以上のもの 38 例につい て, 横軸 FPG, 縦軸 $\mathrm{s}-\mathrm{A} 1 \mathrm{c}$ の座標上の分布をみると, $y=-0.029 x+8.353$ の判別式が求められる。糖㽷病型 は大部分が判別式直線の上方に位置し, 下方にあるもの はわずかに 3 例であった。一方正常型は大部分が直線の 下方に位置したが上方にあるあのが 12 例みとめられた。

\section{結 論}

FPG，s-A 1 c および FRA をいかに組み合わせれば 効率のよい糖代謝異常のスクリーニングが可能であるか についてはさらに今後の検討が必要であると考える。 